\title{
Public and Private Management of Sub-Saharan African Railways Companies: A Comparative Analysis of Technical Efficiency
}

\author{
Augustin Mapapa Mbangala \\ Kinshasa Higher Institute of Commerce (ISC-Kinshasa), DRC \\ Achraf Tarsim \\ African Development Bank Group, Tunisia
}

The railway sector in Africa, facing recently different reforms, becomes progressively entirely controlled by private consortiums. Studying a panel of 16 sub-Saharan railways companies from between 1995 and 2005, we found private management had a positive effect on technical efficiency as measured by Data Envelopment Analysis. This approach also showed that public-private partnerships create several distortions in the sector, including the progressive abandonment of passenger transport.

Keywords: sub-Saharan Africa railways, public management, private management - DEA

\section{INTRODUCTION}

The railway sector in Africa, which has recently faced different reforms, has progressively become entirely controlled by private consortiums. Since the 1990s, and under the auspices of the multilateral agencies, sub-Saharan Africa has undertaken an important restructuring of its rail transport. Since then, 13 countries have adopted operating concessions to manage their companies, and others are in the going through the same process of adopting private management. This trend appears to be the result of authorities' willingness to improve railways companies' management and to cope with the challenge of financial resources availability to maintain their networks.

Private management has the advantage of offering a set of factors that can reduce the huge opportunity costs of public enterprises. However, the problems associated with asymmetric information and divergent interests persist under private management, though they take another form. The establishment of regulatory instruments does not occur in a theoretical framework, where information sharing is transparent and interests of both parties (concessionaire and conceding) are fully respected (with profit the collective interest). Thus, several market distortions could appear after the beginning of private sector participation in railways.

Private management tends to limit its operations to profitable lines and abandon non-profitable ones, regardless of their general public utility. This distortion occurs particularly often when the authority faces serious challenges in its public finances and cannot subsidize the private sector, for a general public utility goal, to continue unprofitable operations. In this context, should we not question the performance of railways operating under a private concession to that of railways that remained under public management? 
This question is particularly relevant insofar as the reforms implemented have resulted in the transfer of a public natural monopoly to a private monopoly.

The methodological approach to estimating railways company performance relies on a benchmark to a defined frontier representing the various the productive efficiencies of a group of companies (Westermann 1999, Weill, 2006). Therefore, the study emphasizes the view of improving production rather than maximizing profit (Avkiran 1999, Coelli and al., 2003). The results obtained with Data Envelopment Analysis (DEA), a nonparametric method, provide direct information to stakeholders in the African rail industry (mainly African governments, international institutions, private operators and regulation authorities) about the performance variations observed between public and private management. This study considers a sample of 16 railways companies of sub-Saharan Africa for the period 1995-2005. Seven of the sample firms have experienced change of their management from public managed enterprise to a concessional management involving private operator.

The remainder of the article is organized in three sections. The situation of railways sector in Africa is described in the first, while the methodological approach and the analytical variables are described in Section 2. Finally, the results are discussed in Section 3.

\section{SUB-SAHARAN AFRICAN RAILWAYS SECTOR}

An analysis of available data on the quality of railway lines highlights their advanced state of decay due to their age, poor maintenance, and inadequate design for effective and modern railways operations. In Africa, most railway networks were built during the period of colonization in the late 19th or early 20th century (Table 1). All of the region's railways are characterized by a single track and the absence of electrified lines, with the exception of South Africa, which has $8411 \mathrm{~km}$ of electrified lines, representing 42 per cent of the Spoornet network, and the Democratic Republic of Congo, with $858 \mathrm{~km}$ representing 24

per cent of the "Société nationale de Chemins de fer du Congo (SNCC) network. In addition, the density of rail networks is low in the African countries retained in the current sample. This could be explained by the fact that the rail structure, inherited from the European colonizers by the African authorities, has been extended since. Indeed, some portions have become unusable due to lack of maintenance, and the number of lines built by the post-colonial leaders is insignificant. Among the most important, we should report the construction of the Tanzania-Zambia line by the Chinese during the 1970s (TAZARA), the construction of Trans-Gabonese $649 \mathrm{~km}$ single-track lines completed in 1987, the extension of $625 \mathrm{~km}$ of lines on the section between Yaounde and Ngaoundere in Cameroun, as well as the modernization of the colonial network from Douala to Yaounde. From 1958 to 1961, Nigeria built $623 \mathrm{~km}$ of track between Maiduguri and Kuru, and further extended this railroad $302 \mathrm{~km}$ to Maiduguri in 1964, bringing the total length of the Nigerian railway company (NRC) network to 3505 kilometers.

We can note based on the data in Table 1 that there is less than one kilometer of lines per 1,000 inhabitants for all sub-Saharan Africa countries. ${ }^{1}$ The comparison of evolutions in the railway infrastructure with that of the population reflects the discrepancy between human geography and transportation (Estache, 2005). Indeed, we find that the African population has grown considerably from 1960 to 2005, in some countries doubling or even tripling, without any corresponding increase in railways capacity.

In sub-Saharan Africa, the organization of transport is reserved for each state, which defines the transport policy and its implications on national development. Thus, until the end of the 1980s, almost all African railway companies were government-managed as industrial and commercial public entities. 
TABLE 1

RAIL CONFIGURATION IN SUB-SAHARAN AFRICA

\begin{tabular}{|c|c|c|c|c|c|c|c|}
\hline \multirow[t]{2}{*}{ Country } & \multirow[t]{2}{*}{ Company } & \multicolumn{2}{|c|}{ Lines (km) } & \multirow{2}{*}{$\begin{array}{l}\text { Construction } \\
\text { period }\end{array}$} & \multirow{2}{*}{$\begin{array}{c}\text { Network } \\
\text { density } \\
(000 \\
\text { area }) \\
\mathrm{Km} / \mathrm{km}^{2}\end{array}$} & \multirow{2}{*}{$\begin{array}{c}\begin{array}{c}\text { Network } \\
\text { density }\end{array} \\
\text { (000 Pop.) } \\
\text { Km/pop. }\end{array}$} & \multirow{2}{*}{$\begin{array}{c}\text { Gauge } \\
\text { (m) }\end{array}$} \\
\hline & & Total & Operating & & & & \\
\hline \multicolumn{8}{|l|}{ Western Africa } \\
\hline Benin-Niger & OCBN & 579 & 438 & 1902-1935 & 5.12 & 0.08 & 1.000 \\
\hline $\begin{array}{l}\text { Burkina Faso- } \\
\text { Ivory Coast }\end{array}$ & SITARAIL & 1250 & 1250 & 1904-1954 & 2.09 & 0.04 & 1.000 \\
\hline Senegal & $\begin{array}{c}\text { SNCS } \\
\text { (Transrail) }\end{array}$ & 906 & 906 & 1882-1934 & 4.60 & 0.08 & 1.000 \\
\hline Ghana & GRC & 947 & 947 & $\mathrm{Na}$ & 3.95 & 0.05 & 1.067 \\
\hline Nigeria & $\mathrm{NRC}$ & 3505 & 3505 & $\begin{array}{c}\text { 1898-1927 } \\
1964\end{array}$ & 3.79 & 0.03 & 1.067 \\
\hline \multicolumn{8}{|l|}{ Central Africa } \\
\hline Cameroon & CAMRAIL & 1100 & 1100 & $\begin{array}{l}1906-1933 \\
1964-1974\end{array}$ & 2.36 & 0.08 & 1.000 \\
\hline $\begin{array}{l}\text { Congo } \\
\text { Brazzaville }\end{array}$ & $\mathrm{CFCO}$ & 795 & 610 & $1922-1934$ & 2.32 & 0.23 & 1.067 \\
\hline Gabon & SETRAG & 649 & 649 & 1974-1986 & 2.42 & 0.52 & 1.435 \\
\hline \multicolumn{8}{|l|}{ Eastern Africa } \\
\hline Tanzania & $\mathrm{TRC}$ & 2605 & 2605 & 1901-1948 & 3.77 & 0.10 & 1.000 \\
\hline $\begin{array}{l}\text { Tanzania- } \\
\text { Zambia }\end{array}$ & TAZARA & 1866 & 1866 & 1970-1976 & & & 1.067 \\
\hline Kenya & $\begin{array}{c}\mathrm{KRC} \\
(\mathrm{RVRC})\end{array}$ & 2065 & 2065 & 1901-1948 & 3.56 & 0.08 & 1.000 \\
\hline \multicolumn{8}{|c|}{ Southern Africa } \\
\hline DRC & SNCC & 3641 & 3641 & before 1930 & $1.92 *$ & 0.09 & 1.067 \\
\hline Malawi & CEAR & 797 & 797 & before 1934 & 6.73 & 0.07 & 1.067 \\
\hline \multirow[t]{4}{*}{ Mozambique } & CCFB & 994 & 994 & 1883-1962 & & & 1.067 \\
\hline & $\mathrm{CDN}$ & 904 & 904 & 1883-1962 & & & 1.067 \\
\hline & CFM & 1048 & 1048 & 1883-1962 & & & 1.067 \\
\hline & Other & 182 & 182 & $1883-1962$ & 3.93 & 0.18 & 1.067 \\
\hline Zambia & $R S Z$ & 1351 & 1351 & $1905-1928$ & 3.00 & 0.21 & 1.067 \\
\hline
\end{tabular}

Since the 1990s, the African railway sector has started to undertake important reforms after the failure of the Strategic Plan approach adopted by the sample companies (contrat programme) of the $1980 \mathrm{~s}^{2}{ }^{2}$ The reform has turned to a new management model, the exploitation (or operational) concession in which the 
state retains ownership of existing investments (e.g., infrastructure) and transfers the activity operations to the concessionaire, with several conditions specified in a concession agreement (Estache and al., 2006). The railway activity is operated by the concessionaire as a commercial activity. Some 14 railways firms of the 33 present in sub-Saharan Africa have adopted operational concession as a management model (Table 2). In general, the scheme held in public-private partnership lies midway between the lease and the concession. In a lease model, the public authority transfers the risk of operating expenses and products to the private operator without carrying the investment and financial risk (e.g., SITARAIL). The concession is a contract making the concessionaire responsible for the management of railways operations, defining the investment policy and the responsibility for maintenance of the equipment and infrastructure. Thus, in the concession management model, the conceding party (government) transfers all risks (CAMRAIL and other concessions) but retains ownership of infrastructure and other assets, as specified in the agreement.

The duration of the public-private partnership contracts vary from 15 to 30 years depending on the country (Table 2). These contracts stipulate that rail activities must be operated by the private operator (concessionaire) according to market rules. This means that the price is set in accordance with the law of supply and demand, and it is supposed to meet a number of criteria considered in the contracts (purchasing power, inflation rate, etc.).

it is worth to note that the private sector involvement in the shareholding of the considered companies varies from country to another and depending on the concession type. The companies' shareholders are mainly foreign private operators (Table 2). With the exception of a few countries (South Africa, DRC and Zimbabwe), where no study has yet suggested reforms for the institutional framework of the railway, all other countries in the region have begun to implement reforms. The concession implementation process is in advanced level in many railways companies, including Djibouti-Ethiopia (CDE) and Congo-Ocean (CFCO).

Turning to the exploitation, we note that railway activity is dominated by freight and long-distance (inter-city) passenger traffic. Few companies exploit suburban railway lines, such as the Dakar-Tiaroye section (Blue Train of Senegal), the urban railway of Kinshasa (DRC) operated by CFMK (Railway Matadi-Kinshasa, managed by ONATRA) and suburban public transport in Tanzania and Kenya. 


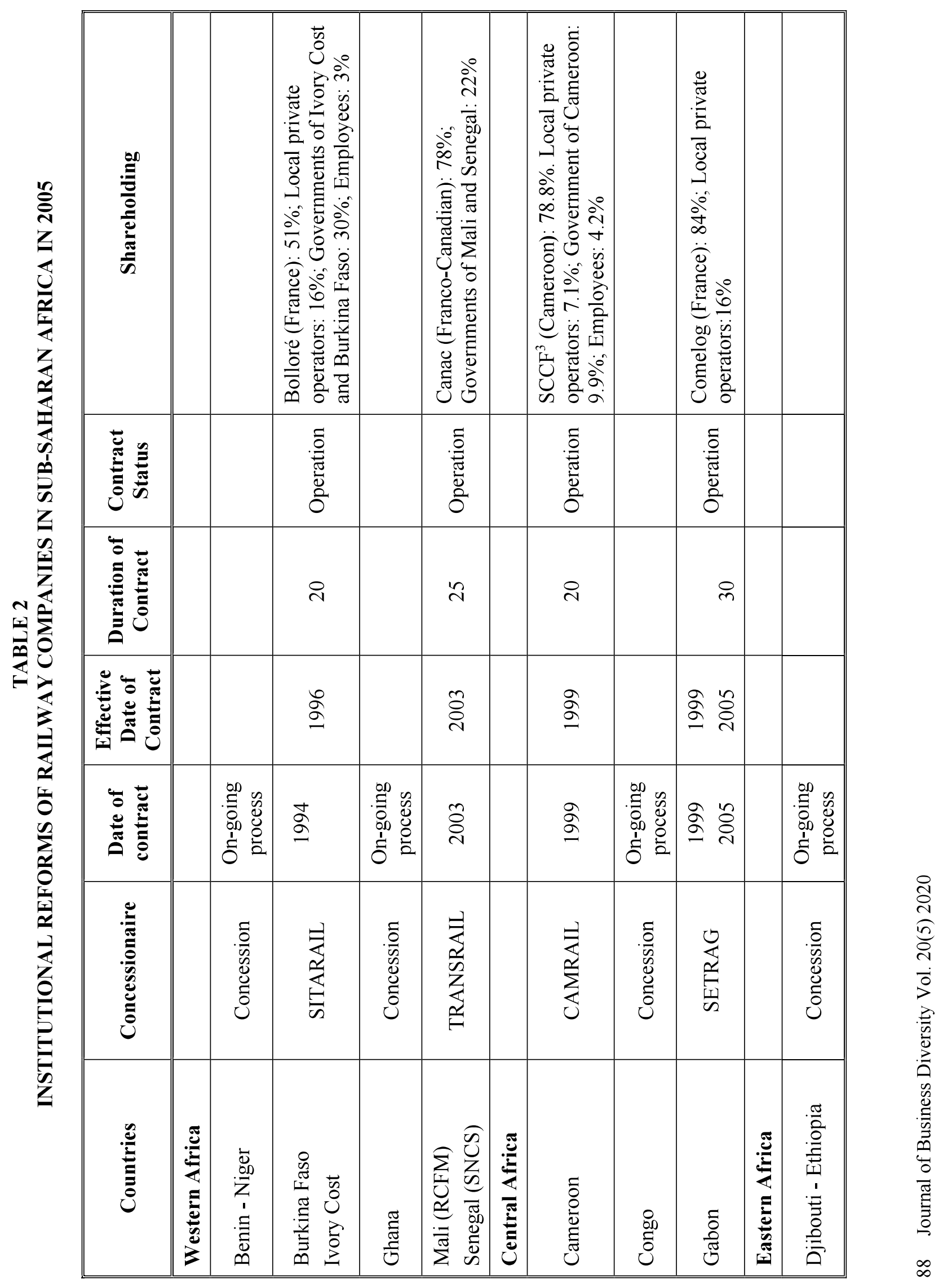




\begin{tabular}{|c|c|c|c|c|c|c|c|c|}
\hline 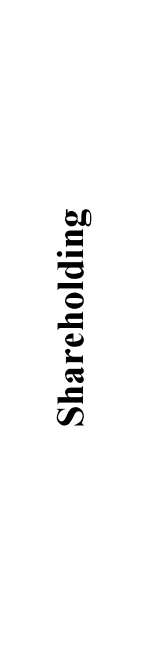 & 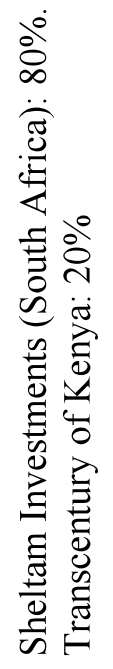 & 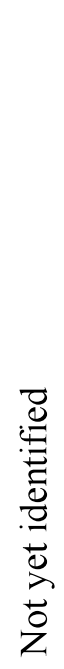 & & 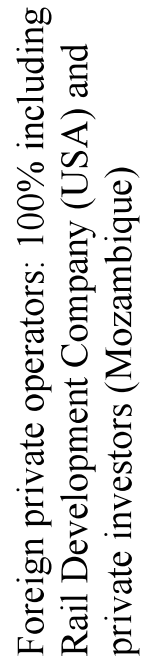 & 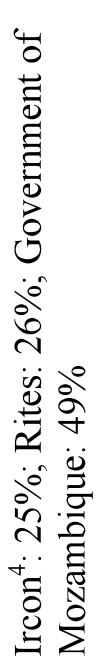 & 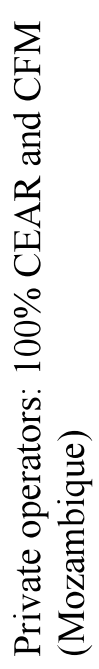 & 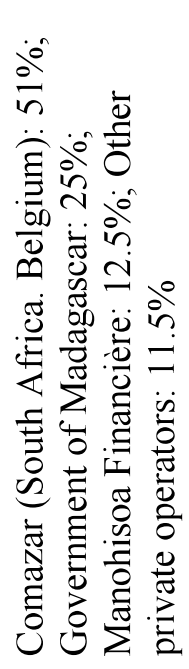 & 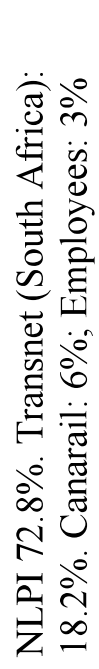 \\
\hline 䒿 & 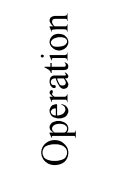 & 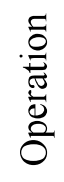 & & 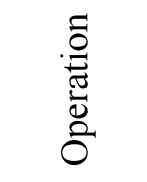 & 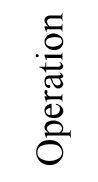 & 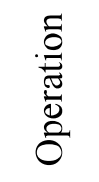 & 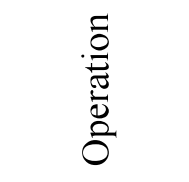 & 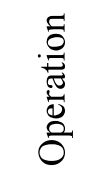 \\
\hline 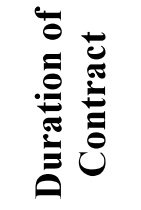 & $\stackrel{n}{\sim}$ & $\stackrel{\sim}{\sim}$ & & 오 & $\stackrel{n}{\sim}$ & $\stackrel{n}{n}$ & $\approx$ & $\stackrel{\curvearrowright}{\curvearrowright}$ \\
\hline 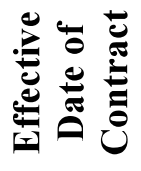 & ஜ̊ & ' & & & ষ্ণ & 号 & §ీ̊ & 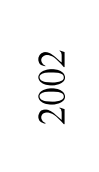 \\
\hline 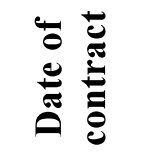 & \&̊ & $\begin{array}{l}0 \\
\stackrel{8}{\circ}\end{array}$ & & જ̆ & ষ্ণ & ஓి & ڤి & ঠి \\
\hline 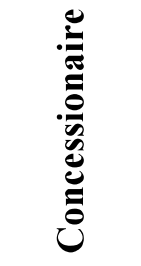 & $\underset{q}{\mathcal{x}}$ & $\underset{\mathscr{V}}{\mathscr{F}}$ & & 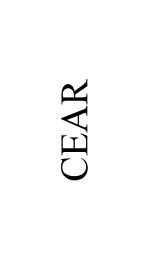 & 兄 & 妄 & $\frac{\equiv}{\grave{2}}$ & $\begin{array}{l}N \\
\text { బ }\end{array}$ \\
\hline 苞 & 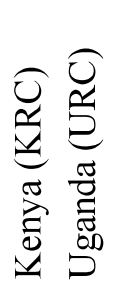 & 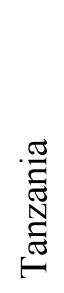 & & $\frac{\sqrt{\frac{\pi}{J}}}{\sum^{\frac{\pi}{2}}}$ & 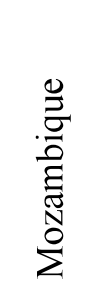 & 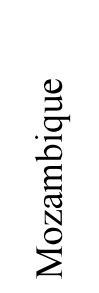 & 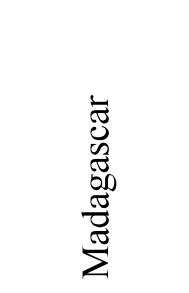 & $\begin{array}{l}\frac{\pi}{0} \\
\frac{\tilde{E}}{N} \\
\text { N }\end{array}$ \\
\hline
\end{tabular}

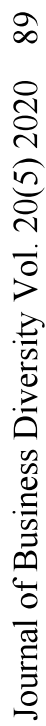




\section{METHODOLOGY AND DATA}

The methodology of production frontier DEA allows measurement of the firm's technical efficiency. With this method, a company is considered technically efficient when, for a given set of production factors, it maximizes its output. In other words, when, for a given level of production, it minimizes the production resources used. This approach is appropriate to compare the productive performance of companies in the same industry and at an international level. To construct a production frontier reflecting best practices, we assume that managers control fully the inputs and the outputs are considered as exogenous factors. Thus, the approach is considered output oriented.

DEA proposes to optimize for each firm a problem of linear programming to determine its efficiency relatively to the frontier enveloping the data of the enterprises (Badillo, 1999). This method could be described as follows: given a set of $M(m=1,2, \ldots, M)$ outputs and $K(k=1,2, \ldots, K)$ inputs for $I(i=1,2, \ldots, S, \ldots, I)$ firms, the technical efficiency is obtained by the maximization of the ratio:

$\operatorname{Max} \sum_{m=1}^{M} U_{m} Y_{m, s} / \sum_{k=1}^{K} V_{k} X_{k, s}$

Under the restrictions:

$$
\begin{aligned}
& \sum_{m=1}^{M} U_{m} Y_{m, i} / \sum_{k=1}^{K} V_{k} X_{k, i} \leq 1, \quad i=1, \ldots, I \\
& U_{m} \geq 0, m=1, \ldots, M \\
& V_{k} \geq 0, k=1, \ldots, K
\end{aligned}
$$

Equation 1 is based on the assumption that the returns of scale are constant (Farrell, 1957) and the inputs are fully under the firm's control. The production frontier is composed by DMUs with an efficiency score equal to $1 . U_{m}$ and are unknown parameters estimated based on the output and input weight, respectively. Thus, the technical efficiency of the $i^{\text {th }}$ firm is the ratio of outputs to inputs reflected in equation (1) under the condition that this ratio is less than 1 for all other firms considered. The maximization of this ratio requires its transformation to a linear programming form. For this, we suppose $t=\sum_{k} V_{k} X_{k s} ; u_{m}=U_{m} / t$ for $M(m=1,2, \ldots, M)$ and $v_{k}=V_{k} / t$ for $K(k=1,2, \ldots, K)$. This gives:

$$
\operatorname{Max} \sum_{m=1}^{M} u_{m} Y_{m, s}
$$

Under the restrictions:

$$
\begin{array}{ll}
\sum_{m=1}^{M} u_{m} Y_{m, i}-\sum_{k=1}^{K} v_{k} X_{k, i} \leq 0, \quad i=1, \ldots, I \quad & \sum_{k=1}^{K} v_{k} X_{k s}=1 \\
u_{m} \geq 0, m=1, \ldots, M & \\
v_{k} \geq 0, k=1, \ldots, K &
\end{array}
$$

Using the duality propriety of the linear programming, we obtain the equivalent program of maximization as in Equation 2 as an envelopment formula: 
Under the restrictions $h_{s} x_{k s}-\sum_{i=1}^{I} x_{k i} \lambda_{i} \geq 0 ; \sum_{i=1}^{I} y_{m i} \lambda_{i}-y_{m s} \geq 0$ and $\lambda_{i}(i=1, \ldots, N) \geq 0$.

Here, $h_{s}$ is the technical efficiency score, which is equal to one if the firm is efficient. The multipliers $\lambda_{i}$, called peers, indicate how the best practice frontier relative to which the $s^{\text {th }}$ firm is compared is formed. Therefore, the measured efficiency is obtained under the assumption of constant returns to scale (CRS) in a manner similar to the model of Charnes, Cooper and Rhodes (1978). To consider the general model of variable returns to scale (VRS) as developed by Banker, Charnes and Cooper (1984) we add a new restriction $\sum \lambda_{i}=1$ to the linear program in Equation 3.

The original dataset is a panel of 16 railway companies for the period 1995-2005, in which seven companies have experienced an operational concession (CAMRAIL, CEAR, CCFB, CDN, SETRAG, SITARAIL, RSZ) and nine remain public-managed (CFM, CFCO, GRC, KRC, NRC, OCBN, SNCC, TAZARA, TRC). Among these companies, four have large networks of greater than $2000 \mathrm{~km}$ (SNCC, NRC, TRC and KRC); five are of medium size, 1000 to $2000 \mathrm{~km}$ (CAMRAIL, SITARAIL, TAZARA, CFM, RSZ); and seven firms are considered small, with less than $1000 \mathrm{~km}$ of track (CCFB, CEAR, CFCO, OCBN, SETRAG, GRC, CDN).

Our analysis uses the annual physical variables of inputs and outputs measured in their units of origin. Two inputs and two outputs are considered. The number of permanent staff and amount of equipment (represented by the sum of passenger vehicles and freight wagons) are the input variables. The passenger per kilometers and the tons per kilometers represent the output variables (Table 3).

The observation of output data shows that the passenger traffic of public companies is twice that of companies under private management. Conversely, freight traffic is higher for privately managed companies than for those under public management. The strong dispersion of variables within each group should be noted (Table 3 ).

TABLE 3

ANALYTICAL VARIABLES (AVERAGE 1995-2005)

\begin{tabular}{lrrrr}
\hline & P-km & T-km & Staff & Equipment \\
\hline Public companies & 255 & 561 & 7458 & 2010 \\
Concessioned companies & 125 & 589 & 2403 & 1645 \\
All companies & & & & \\
Maximum & $\mathbf{8 3 4}$ & $\mathbf{2 2 0 8}$ & $\mathbf{1 7 9 5 7}$ & $\mathbf{8 9 3 4}$ \\
Minimum & $\mathbf{1 5}$ & $\mathbf{2 0}$ & $\mathbf{2 8 6}$ & $\mathbf{2 8 5}$ \\
Mean & $\mathbf{1 9 9}$ & $\mathbf{5 7 7}$ & $\mathbf{5 2 4 6}$ & $\mathbf{1 7 3 4}$ \\
Standard variation & $\mathbf{1 7 6}$ & $\mathbf{5 1 0}$ & $\mathbf{4 5 8 5}$ & $\mathbf{1 9 2 9}$ \\
\hline
\end{tabular}

P-km: passenger kilometer, T-km: ton per kilometer, Equipment: passengers cars + freight wagons

The evolution of rail traffic is characterized not only by declining passenger traffic, but also by the abandonment of passenger service by several railways firms. Indeed, most Sub Saharan African states are no longer able to guarantee this public service is provided. Private operators are not interested in unprofitable activities in the absence of sufficient subsidies. Notably, despite the decrease in passenger 
service, data show an increase of freight traffic for most companies, particularly those managed by private operators (Table 4).

TABLE 4

AVERAGE GROWTH RATE OF TRAFFIC AND STAFF (\%)

\begin{tabular}{lcccc}
\hline & P-km & T-km & Traffic Unit & Staff \\
\hline Public companies & -1.59 & 0.44 & -0.91 & -3.81 \\
Concessioned companies & -0.13 & 9 & 4.39 & -4.92 \\
All companies & -0.88 & 4.9 & 1.74 & -4.38 \\
\hline
\end{tabular}

P-km: passenger kilometer, T-km: ton per kilometer, Traffic unit $=\mathrm{P}-\mathrm{km}+\mathrm{T}-\mathrm{km}$

The staff reduction in the African rail industry since the beginning of the 1990s has substantially changed employment policies. Table 4 shows that the average rate of job loss is 4.38 per cent annually among African railway firms of the sample. The reduction of employment is more pronounced in concessioned companies with an annual average of -4.92 per cent, compared to -3.81 per cent for public managed companies.

\section{RESULTS}

The results show that companies are generally inefficient. The average score of efficiency for the sample is 0.471 for the technical efficiency with variable returns to scale (VRS) and 0.632 for technical efficiency with constant returns to scale (CRS), with respective dispersion of results of 0.264 and 0.245. Privately managed companies have higher average efficiency than public-managed ones, which suggests that concessioned companies are more efficiently managed than public companies. The seven concessioned firms have the highest efficiency scores, as shown by the firms' efficiencies reported in appendix table 1. In addition to this finding, we can observe (appendix table 1) that firms that have experienced institutional reform improved their efficiency in the latter half of the considered period, 2000-2005.

Conversely, the average level of scale efficiency of public companies is higher than that of companies under concession. This indicates that companies under private management might increase their efficiency if they grow, which could be done interconnecting existing railway networks. This conclusion is in line with the perspectives of the leaders of West Africa that have established an "AFRICARAIL" framework, with the stated aim to link the countries of the Economic Community of West Africa (ECOWAS) by railroads.

We note that there are significant differences in scale between the public companies and those under private management: the four biggest firms of the sample are public. The higher efficiency of privately managed companies could result not only from better management, but from differences in scale. Thus, to determine the effect of the production scale on the efficiency scores, we consider a distribution graph presenting efficiency scores by the size of companies in terms of network length (Figure 1). 
TABLE 5

AVERAGE EFFICIENCY SCORES BY COMPANY TYPE

\begin{tabular}{|c|c|c|c|c|c|c|}
\hline \multirow[t]{2}{*}{ Efficiency } & \multicolumn{2}{|c|}{ Public companies } & \multicolumn{2}{|c|}{ Concessioned companies } & \multicolumn{2}{|c|}{ All companies } \\
\hline & Mean & Std. dev. & Mean & Std. dev & Mean & Std. dev. \\
\hline $\begin{array}{l}\text { VRS technical } \\
\text { efficiency }\end{array}$ & 0,436 & 0,224 & 0,511 & 0,305 & 0,471 & 0,264 \\
\hline $\begin{array}{l}\text { CRS technical } \\
\text { efficiency }\end{array}$ & 0,548 & 0,245 & 0,740 & 0,239 & 0,632 & 0,245 \\
\hline Scale efficiency & 0,801 & 0,202 & 0,548 & 0,245 & 0,748 & 0,201 \\
\hline
\end{tabular}

VRS: Variable Returns to Scale, CRS: Constant Returns to Scale

Figure 1 does not enable us to conclude that the totally inefficient networks are those with more than $2000 \mathrm{~km}$ of lines. Indeed, we found also small companies in the portion of the graph containing less efficient firms (i.e. with scores $<60$ per cent). However, companies with efficiency scores above 80 per cent are exclusively those with small or medium networks.

FIGURE 1

DISTRIBUTION OF EFFICIENCY SCORES BY COMPANIES' SIZES (NETWORK)

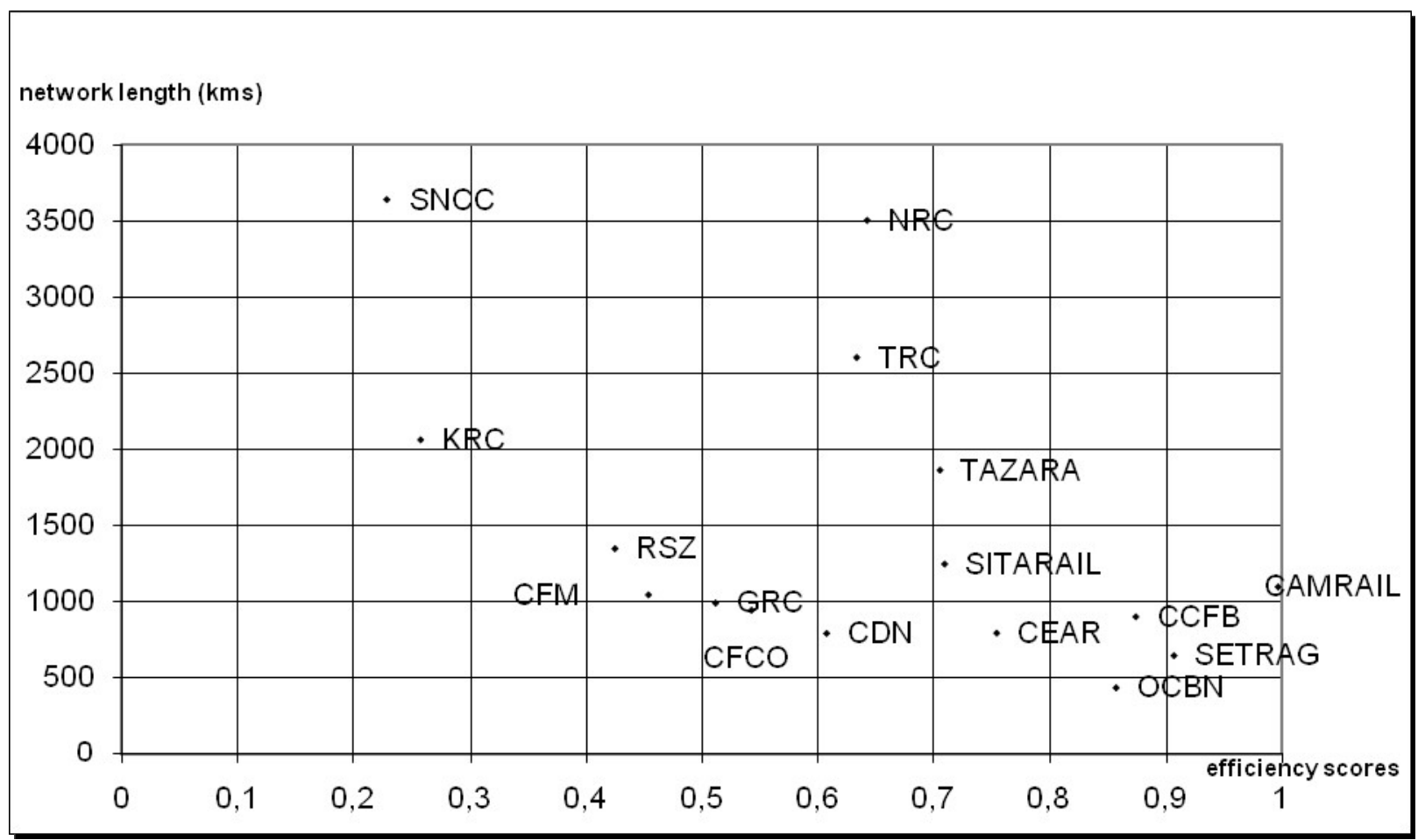

The railways companies exist in a global context. This operational context is specific for each company, because it depends on the economic, political and social environment of a given country. Therefore, we should consider the effects of these exogenous factors on the efficiency already measured by DEA. The 
variable to be explained (efficiency score) by the exogenous factors is between 0 and 1 , so a Tobit regression is appropriate to test the robustness of the results obtained by ordinary least squares.

We consider five explanatory variables to explain the efficiency scores: temporal trend, network density ( $\mathrm{km}$ of lines per inhabitant), the gross domestic product per capita expressed in constant dollars (with base year 2000), the share of passenger traffic (as a percentage of total traffic) and the institutional management status (represented by a dummy variable: 0 for public firms and 1 when a concession is implemented). Table 6 presents the results of ordinary least squares and Tobit regressions.

\section{TABLE 6 EXPLANATORY FACTORS OF TECHNICAL EFFICIENCY}

Ordinary least square (OLS) and TOBIT models

Dependent variables: DEA scores (\%)

\begin{tabular}{lrlrl}
\hline \multicolumn{1}{c}{ Explanatory Factors } & \multicolumn{2}{c}{ OLS } & \multicolumn{2}{c}{ Tobit } \\
\hline Constant & Parameters $($ t-ratios $)$ & Parameters $($ t-ratios $)$ \\
Trend & 32.8 & $(6.16)^{* *}$ & $31.8 \quad(5.41)^{* *}$ \\
Population density & 1.079 & $(1.89)^{*}$ & $1.172 \quad(1.86)^{*}$ \\
Share P-km in \% of TU & -0.018 & $(-0.29)$ & $-0.036 \quad(-0.53)$ \\
GNP per capita & 0.537 & $(4.65)^{* *}$ & $0.604 \quad(4.72)^{* *}$ \\
Concessioned companies & 0.0074 & $(3.67)^{* *}$ & $0.0078 \quad(3.41)^{* *}$ \\
$\mathrm{R}^{2}$ (pseudo R $\left.{ }^{2}\right)$ & 29.21 & $(6.37)^{* *}$ & 33.43 & $(6.48)^{* *}$ \\
Number of observations & 0.338 & $(0.196)$ \\
\hline Censored observations & 176 & 176 \\
\hline
\end{tabular}

**, *Parameters are significant at $1 \%$ and $10 \%$

TU: Traffic unit

Interestingly, the results of both models are similar; indeed, the signs and significance of the variables are identical. Furthermore, most parameters are statistically significant. The global fit of both models is robust: the least square models determination coefficient $\left(\mathrm{R}^{2}\right)$ is 0.33 ; the pseudo $\mathrm{R}^{2}$ of the TOBIT model is 0.19 , which confirms the explanatory power of variables used in the model.

The econometric results could be interpreted as follows:

a. Variables such as temporal trend, share of P-km, GDP per capita and concessioned status are associated with positive and significant parameters at the level of 10 per cent for trend, and 1 per cent for the other factors.

b. Increase in passenger traffic has a positive impact on the efficiency score. This confirms our finding: companies that have succeeded in developing passenger traffic have high efficiency scores as, all other things being equal, including equal staffing, the company that increases its passenger traffic improves its performance.

c. We found that companies' production (freight traffic) appears to reflect a country's economic health. Hence, a higher GDP will contribute to better technical performance.

d. The coefficient associated with the "concessioned status" variable is statistically significant and positive in both tests. This suggests that the change in legal status from public to privately managed company has resulted in significantly improved technical efficiency. This may be explained by the convergence of owners and managers interests in the concessioned companies. 
Furthermore, the managers of these firms follow western corporate governance standards and have "know-how" in organization and risk analysis. These are all elements contributing to the higher efficiency of privately managed enterprises.

e. High population density has a positive impact on companies' technical performance (cause and effect relationship).

f. Companies improved their efficiency over time (temporal trend variable); most improvements took place during the second sub-period, 2000-2005, when several companies initiated institutional reforms.

\section{CONCLUSION}

Railways networks in Africa were generally constructed during the period of colonization. Given their age and a lack of maintenance, these networks are characterized by an advanced state of decay. The absence of interconnections between the lines is also a specific characteristic of the sub-Saharan railway sector.

Non-parametric efficiency estimation indicates that African railways are generally inefficient, with average scores of 0.471 and 0.632 for VRS and CRS efficiencies, respectively. The results of DEA also show that the privately managed rail companies are more efficient than the publicly managed ones.

Regression analysis revealed information about the explanatory factors of the observed technical efficiency. Indeed, addionnal effort to develop passenger transport activity relative to freight has a positive effect on efficiency. Furthermore, the implementation of a concession management framework increases railways' technical efficiency. This suggests that companies experiencing a public-private partnership are better managed than public companies.

Our analysis highlighted the reduction of passenger transport activity relative to the freight transport, particularly for privately managed companies. The unprofitability of passenger activity and the absence of public subsidies supporting it explain this tendency to abandon such activity. This could be considered problematic given the importance of long distance and suburban rail lines for population mobility. In this sense, it is relevant for the relevant political authorities, with the support of international financial institutions, to find appropriate solutions for revitalizing passenger transport activity, since this type of traffic improves railways' productivity as well as their effectiveness.

The implementation of public-private partnerships is an important solution to reduce the opportunity costs of private companies and allows improvement in the efficiency over public management. Nevertheless, these agreements are not sufficient to eliminate all of the problems associated with the asymmetry of information and divergent interests of the economic partners. This issue of optimal contract, enforcing the respect of the mutual commitments between private operators and public authorities, should be investigated further.

\section{ACKNOWLEDGEMENT}

Translated \& edited by American Publishing Services (https://americanpublishingservices.com/)

\section{ENDNOTES}

1. To measure the densities of network (relative to area and population) for SITARAIL, we combined the areas and populations of both Burkina Faso and Ivory Coast.

2. The failure in the application of the strategic plan is mainly due to the fact that the central states haven not properly respect their commitments to the railway company, notably by ensuring independent management mechanism.

3. Société Camerounaise des Chemins de Fer., an affiliate of Comazar, a privately operated and managed company that includes South Africa's Spoornet and Transurb Consult, an affiliate of the Belgian National Railways, among its shareholders.

4. Indian Railways Construction Corporation. 


\section{REFERENCES}

Avkiran, N. (1999): An application reference for data envelopment analysis in branch banking: Helping the novice researcher. International Journal of Bank Marketing, 5, 206-220.

Badillo, P.Y., \& Paradi, J.C. (1999). La méthode DEA, analyse des performances. Hermes Science Publications, Paris.

Banker, R.D., Charnes, A., \& Cooper, W. (1984). 'Some models for estimating technical and sale inefficiencies in Data Envelopment Analysis. Management Science, 9, 1078-1092.

Charnes A., Cooper, W., \& Rhodes, E. (1978). Measuring Efficiency of Decision Making Units. European Journal of Operations Research, 6, 429-444.

Coelli, T.J., Estache, A., Perelman, S., \& Trujillo, L. (2003). A Primer on Efficiency Measurement for Utilities and Transport Regulators. World Bank Institute Publications, Development Studies Series.

Estache, A. (2005). How Much Do We Know About Sub-Saharan Africa's Infrastructure and the Impact of its 1990 Reforms? Mimeo, World Bank.

Estache, A., Perelman, S., \& Trujillo, L. (2006). Infrastructure Reform in Developing Economies: Evidence from a Survey of Economic Performance Measures. In T.J. Coelli \& D. Lawrence (Eds.), Performance Measurement and Regulation of Network Utilities (pp. 133-174). Edward Elgar. Cheltenham, UK.

Farrell, M.J. (1957). The Measurement of Productive Efficiency. Journal of the Royal Statistical Society, Series A, General, 120, 253-281.

Pozzo di Borgo, P. (2006). Review of Selected Railway Concessions in Sub-Saharan Africa. World Bank Report.

Weill, L. (2006). 'Propriété étrangère et efficience technique des banques dans les pays en transition. Une analyse par la méthode DEA. Revue Economique, 5, 1093-1108.

Westermann, G. (1999). La banque et les télécommunications. In P.Y. Badillo \& J.C. Paradi (Eds.), La méthode DEA, analyse des performances (pp. 129-215). Hermes Science Publications, Paris. 


\section{APPENDIX \\ FIRMS' EFFICIENCY SCORES}

\begin{tabular}{|c|c|c|c|c|c|c|c|c|c|}
\hline \multirow[b]{4}{*}{ Concessioned firms } & \multicolumn{3}{|c|}{ VRS Efficiency scores } & \multirow{2}{*}{\multicolumn{3}{|c|}{$\frac{\text { CRS Efficiency scores }}{\text { Periods }}$}} & \multirow{2}{*}{\multicolumn{3}{|c|}{$\frac{\text { Scale Efficiency scores }}{\text { Periods }}$}} \\
\hline & \multicolumn{3}{|c|}{ Periods } & & & & & & \\
\hline & $95-99$ & $\begin{array}{l}00- \\
05\end{array}$ & $95-05$ & $95-99$ & $00-05$ & $95-05$ & $95-99$ & $00-05$ & $95-05$ \\
\hline & & & & & & & & & \\
\hline CAMRAIL (Cameroon) & 0.744 & 0.936 & 0.849 & 0.998 & 0.996 & 0.997 & 0.745 & 0.940 & 0.852 \\
\hline CCFB (Mozambique) & 0.206 & 0.153 & 0.177 & 0.364 & 0.653 & 0.512 & 0.566 & 0.269 & 0.404 \\
\hline CDN (Mozambique) & 0.604 & 0.550 & 0.574 & 0.798 & 0.937 & 0.874 & 0.747 & 0.583 & 0.657 \\
\hline CEAR (Malawi) & 0.143 & 0.199 & 0.173 & 0.730 & 0.776 & 0.755 & 0.203 & 0.256 & 0.232 \\
\hline RSZ (Zambia) & 0.246 & 0.383 & 0.321 & 0.346 & 0.490 & 0.425 & 0.711 & 0.773 & 0.744 \\
\hline SETRAG (Gabon) & 0.802 & 0.903 & 0.857 & 0.881 & 0.908 & 0.907 & 0.910 & 0.972 & 0.944 \\
\hline $\begin{array}{l}\text { SITARAIL (Burkina } \\
\text { Faso \& Ivory Coast) }\end{array}$ & 0.462 & 0.764 & 0.627 & 0.548 & 0.846 & 0.710 & 0.815 & 0.902 & 0.863 \\
\hline$\underline{\text { Public firms }}$ & & & & & & & & & \\
\hline CFCO (Congo) & 0.497 & 0.452 & 0.472 & 0.608 & 0.607 & 0.608 & 0.747 & 0.732 & 0.739 \\
\hline CFM (Mozambique) & 0.216 & 0.321 & 0.273 & 0.320 & 0.565 & 0.454 & 0.676 & 0.540 & 0.602 \\
\hline GRC (Ghana) & 0.203 & 0.256 & 0.232 & 0.595 & 0.499 & 0.543 & 0.888 & 0.555 & 0.706 \\
\hline KRC (Kenya) & 0.246 & 0.383 & 0.207 & 0.220 & 0.287 & 0.257 & 0.873 & 0.801 & 0.834 \\
\hline NRC (Nigeria) & 0.513 & 0.526 & 0.520 & 0.687 & 0.607 & 0.643 & 0.812 & 0.873 & 0.846 \\
\hline OCBN (Benin \& Niger) & 0.646 & 0.450 & 0.539 & 0.753 & 0.943 & 0.857 & 0.871 & 0.473 & 0.654 \\
\hline $\mathrm{SNCC}(R D C)$ & 0.158 & 0.241 & 0.204 & 0.186 & 0.265 & 0.229 & 0.809 & 0.903 & 0.860 \\
\hline $\begin{array}{l}\text { TAZARA (Tanzania \& } \\
\text { Zambia) }\end{array}$ & 0.780 & 0.627 & 0.696 & 0.790 & 0.636 & 0.706 & 0.986 & 0.983 & 0.984 \\
\hline TRC (Tanzania) & 0.629 & 0.611 & 0.619 & 0.658 & 0.614 & 0.634 & 0.960 & 0.995 & 0.979 \\
\hline Mean & & & 0.471 & & & 0.632 & & & 0.748 \\
\hline
\end{tabular}

